\title{
Stretching the Adjudicative Paradigm: Another Look at Judicial Policy Making and the Modern State
}

Daniel A. Farber

Malcolm Feeley and Edward Rubin. 1998. Judicial Policy Making and the Modern State: How the Courts Reformed America's Prisons. New York: Cambridge University Press. Pp. 490. \$69.95.

In Judicial Policy Making and the Modern State, Malcolm Feeley and Edward Rubin challenge the conventional wisdom regarding the judicial role. They contend that policymaking is a major-and legitimate-part of the judiciary's work. Rather than focusing on the individual judge working in isolation, they view the judiciary as inherently a multimember institution. Their thesis is that the need for coordination among judges imposes constraints on the judiciary in profound ways, which should curb fears of an imperial judiciary. In the course of this argument, they provide sharp critiques of conventional views of how federalism and separation of powers limit the authority of federal judges. Indeed, based partly on theory and partly on their study of prison reform litigation, they go so far as to suggest that federalism and separation of powers are obsolete notions.

If nothing else, their study of prison litigation identifies an important phenomenon, one that should interest a broad range of legal scholars. As they point out, until the mid-1960s, the courts had adopted a hands-off attitude toward prison conditions. But within a few years, the judiciary completely changed course. With the participation of literally hundreds of judges, courts issued sweeping injunctions that took over the management of state prisons. Based on hastily improvised doctrine, these injunctions in-

Daniel A. Farber is Henry J. Fletcher Professor of Law and Associate Dean for Faculty and Research, University of Minnesota. Thanks to Phil Frickey for helpful suggestions on an earlier draft. 
truded deeply on traditional functions of state executive officials. Conventional notions of federalism, separation of powers, and legal process were stretched, perhaps to the breaking point. Yet, this startling innovation received support from trial judges around the country and from the courts of appeals - and at least the benefit of benign neglect even from the increasingly conservative Supreme Court (pp. 13-20, 30-50). As Feeley and Rubin put it, "while an illegitimate action by a single judge, or even by a few judges who constitute the majority of a single court, presents no great explanatory problem, the idea that the entire federal judiciary, without external coordination or command, would violate basic norms of governance seems implausible at best" (p. 146). Feeley and Rubin view this phenomenon as raising basic questions about the role and function of the federal judiciary.

This book should be on the reading lists of legal theorists, constitutional scholars, and students of the federal courts. Although it uses prison reform as the basis for a case study of judicial activism, the authors' agenda is actually far wider; the discussion of the role of the judiciary in modern society is important for many potential readers with no particular interest in prison reform. Indeed, even though the book is being published as part of a criminology series, it may have less to offer students of prison reform, who will not find much new to them about the history, structure, or effectiveness of the litigation. It eloquently retells the story of the prison reform litigation, but the story itself is familiar to those in the field. Unlike those who have studied the varying strategies adopted by federal judges (Sturm 1990), Rubin and Feeley have little interest in the details of the remedial process. And on the critical question from the point of view of prison policy-whether the judges succeeded in their efforts-the book briefly surveys the current literature but does not break new ground (pp. 362-80). Nor will the book provide much guidance for future prison reformers. The book does defend the legitimacy of prison decrees, but as the authors themselves admit, the future of prison reform will have to lie in another direction; judges will no longer be in the forefront (p. 388). In fact, recent federal legislation mandates a rollback of current decrees (Decker 1997). Thus, the book has more to offer as a work of legal theory than as a contribution to criminology.

In terms of legal theory, Feeley and Rubin are entering the late stages of a jurisprudential debate about "public law" litigation that began at least 20 years ago. Thus, a lengthy introduction is required before we can turn to their views. In this essay, I will put the Feeley and Rubin book in perspective by first exploring the problem posed by the prison cases for conventional views of adjudication and then probing the ongoing debate sparked by those cases. I will then turn to the constitutional issues addressed by 
Feeley and Rubin. Finally, I will explore the core of the book: the authors' description of judicial policymaking and defense of its legitimacy.

\section{THE PROBLEM OF STRUCTURAL LITIGATION}

Feeley and Rubin provide a vivid overview of the prison cases. As we will see, prison reform litigation (like that involving schools and mental hospitals) challenges the traditional notion of adjudication in almost every respect (Coffin 989-90). This section will examine the tension between these cases and traditional adjudication; the following section will trace the debate about how to resolve that tension.

\section{A. The Traditional Paradigm}

Lon Fuller provided what is probably the classic explication of the conventional notion of litigation. ${ }^{1}$ According to Fuller, "the distinguishing characteristic of adjudication lies in the fact that it confers on the affected party a peculiar form of participation in the decision, that of presenting proofs and reasoned arguments for a decision in his favor" (Fuller 1978, 364). ${ }^{2}$ Fuller argued that because claims are based on argument and principle, they tend to be understood as "claims of right or accusations of fault" (Fuller 1978, 365-69, 385-88). As a corollary of the last of these propositions, Fuller remarked that adjudication is "not a proper form of social ordering in those areas where the effectiveness of human association would be destroyed if it were organized about formally defined 'rights' and 'wrongs'" (Fuller 1978, 371).

Fuller later returned to the question of what tasks are inherently unsuited to adjudication. His primary conclusion was that adjudication is unsuited for polycentric tasks-tasks in which multiple dimensions are interconnected, so that the proper decision about any one item is inseparable from all of the others. His example was price control, because "the forms of adjudication cannot encompass and take into account the complex reper-

1. Feeley and Rubin echo a common misconception when they link Fuller's views with "the case law method designed by C. C. Langdell in the 1870s" (p. 321), as if Fuller and his fellow legal process theorists were oblivious to the modern administrative state. But in fact, although Fuller does discuss common law litigation, his essay is also replete with references to labor arbitration, administration agencies, international tribunals, and socialist legal institutions (Fuller 1978, 355, 375-76, 379, 387, 396,400, 403). Indeed, he says, "[i]t is in the field of administrative law that the issues dealt with in this paper become most acute" (Fuller 1978, 355). In short, although he does not anticipate the further developments of the past 30 years, Fuller was very much a post-New Deal thinker, not a captive of the pre-New Deal world of classical formalism.

2. Such arguments may be about facts, or about deduction from formal rules, or more importantly, may involve the effort to "trace out and articulate the implications of shared purposes" (Fuller 1978, 381). 
cussions that may result from any change in prices or wages," as when a change in the price of aluminum affects the demand for various other materials (Fuller 1978, 394). ${ }^{3}$

Fuller clearly viewed adjudication as best designed to deal with singledimensional issues, such as the assignment of fault or the calculation of damages (Fuller 1978, 403). Also, he viewed party participation as the key to adjudication, leaving a relatively passive role for the adjudicator, whose role was primarily to assess the competing arguments of the parties. Finally, the standards governing the dispute were assumed to already exist in some form, although perhaps in need of clarification or revision-otherwise, the parties would have nothing on which to ground their arguments.

As we will see, the prison cases fit at best uneasily within Fuller's model. Indeed, one perceptive observer during the heyday of reform litigation contrasted traditional adjudication with the judge's new role as "powerbroker," arguing in Fuller-like terms that judicial legitimacy derives from the adjudicative role and would inevitably be eroded in this newer role (Diver 1979, 106).

\section{B. The Saga of Arkansas Prison Reform}

To assess this change in the judicial role, we need to take a closer look at prison litigation. In the first part of their book, Feeley and Rubin present five vivid case studies of prison reform litigation. The Arkansas litigation was in many respects the paradigm that set the pace for all of the others. Indeed, until Judge Henley arrived on the scene, prison reform litigation did not really exist. For that reason, the Arkansas case is probably the best introduction to the realities of prison reform.

Like many southern prisons, the Arkansas prison at Cummins Farm was run on the pre-Civil War plantation model, with the prisoners playing the role of slaves. Prisoners worked in the fields six days a week, under the supervision of "trustees" (other prisoners who were allowed to administer corporal and sometimes even capital punishment). The prisoners' sleeping area was unsupervised, leaving the way open for homosexual rape and other crimes. For safety, "some of the inmates would come to the front of the barracks and cling to the bars all night." The prison lacked any medical facilities. Prisoners had to pay the trusties to obtain medicine or other amenities; they generally could make money only by selling their blood.

3. Fuller also suggests that part of the problem is nonlinearity. Doubling the pull on one part of a spider's web, rather than doubling the existing stress levels, may create a "different complicated pattern of tensions," for example, by breaking a weak strand. The discussion of nonlinearity is strikingly reminiscent of modern complexity theory (Fuller 1978, 395). Fuller later makes the intriguing suggestion that a flexible doctrine of stare decisis allows the legal process to better handle polycentric tasks by providing for "reformulation and clarification as problems not originally foreseen arise" (Fuller 1978, 398). 
Thus, to obtain medical care, an ordinary prisoner would have to sell his own blood (pp. 53-55).

The litigation began with several pro se habeas corpus petitions. Judge J. Smith Henley appointed two local lawyers to represent the prisoners. Henley's early decisions in the Arkansas case marked the first time a federal judge had given serious scrutiny to prison conditions. He was appalled by what he found. A prominent early issue involved the use of the "Tucker telephone," a device for administering severe electric shocks to the prisoners' genitals. Judge Henley's rulings on this and other issues broke new ground. But federal intervention into the Arkansas prisons was almost immediately endorsed by the Eighth Circuit, in an opinion by Harry Blackmun banning corporal punishment in the prison system (p. 57).

The case expanded to cover a broader range of issues, prompted by an investigative report by the state police ordered by Governor Faubus, which documented "institutionalized torture, near starvation diets, rampant violence, and widespread corruption" (p. 59). In the wake of this report, a reform-minded corrections director was appointed who became the model for the Robert Redford character in the movie Brubaker. In the next round of the litigation, the judge held unconstitutional the prison's isolation units and its failure to guard the prisoners from nocturnal attacks. The new commissioner played an important role in this round of the litigation-indeed, he is widely thought to have helped draft the prisoners' complaint (pp. 60-61).

New lawyers were appointed to represent the prisoners, and they launched a full-scale investigation into the prison. At this point, the judge's intervention became more sweeping. He found conditions in the prison as a whole to violate the Eighth Amendment. "For the ordinary convict," he said, "a sentence to the Arkansas Penitentiary today amounts to a banishment from civilized society to a dark and evil world completely alien to the free world, a world that is administered by criminals under unwritten rules and customs completely foreign to free world culture" (pp. 63-64).

Henley was appointed to the Eighth Circuit by President Ford (p. 71). The case was then reassigned to Judge Eisele. After taking an initially aggressive position, he was able to get the parties to negotiate a consent decree covering 39 aspects of prison operations. Ultimately, some 17 years after the case began, Judge Eisele finally held the prison to be in compliance with the Constitution (pp. 74-78).

Feeley and Rubin leave little doubt about their assessment of the Arkansas litigation as a success:

[T]here is no doubt that the prison system Judge Eisele left in 1982 was significantly different from the one that had greeted Judge Henley seventeen years earlier. . . . Inmates no longer had to bribe brutal inmate overlords to obtain basic necessities. They no longer had to fear for 
their lives every time they went to sleep. They no longer were capriciously deprived of food and medical services. They no longer had to worry that their genitals might be taped to electrodes or their knuckles cracked with pliers. They were no longer stripped to the waist and whipped for failure to pick a sufficient amount of cotton or okra. . . . The Arkansas prison system had entered the twentieth century. (P. $79)^{4}$

\section{The Problem of Structural Litigation}

The Arkansas case strayed far from the conventional model of litigation. For all practical purposes, the case was initiated by the judge, with the actual prisoner complaints serving only as a formality. The judge handpicked the lawyers representing the prisoners' side of the case. Since there was no prior law regarding the application of the Eighth Amendment to prison conditions, his condemnation of existing conditions did not arise from precedent, nor was there any particular effort to ground it in the history or text of the Constitution. More importantly, the remedies did not derive in any logical way from a prior analysis of specific constitutional violations. Instead, the remedial process acquired a life of its own, as the interplay between the judges and their assistants, state officials, and the prisoners' lawyers led to an evolving standard of appropriate imprisonment. In short, the court immersed itself completely in a polycentric, ongoing dispute, rather than adjudicating how some existing legal principle applied to a specific past transaction.

As Feeley and Rubin point out, federal courts behaved in the prison cases very much as a national administrative agency would have done (pp. 303-5). Yet, this deviation from traditional expectations about the judicial role was no isolated aberration. Hundreds of federal judges participated in some phase of these cases. Their actions did not give rise to tremendous controversy (p. 19). For instance, Blackmun's early involvement in the Arkansas litigation did not prevent Nixon from appointing him to the Supreme Court, and Henley's more sustained role apparently gave Gerald Ford no qualms. Moreover, similar (though more controversial) judicial interventions took place in other fields such as school desegregation (Liebman 1990; Eskridge 1989, 955-58). 


\section{THE DEBATE OVER INSTITUTIONAL LITIGATION}

The prison cases and related developments led some scholars to prophesy a new role for judges, which others condemned as an unconstitutional usurpation. We begin with the prophets.

\section{A. Prophets of a New Paradigm}

Among the commentators on institutional litigation, two stand out among its defenders: Abram Chayes and Owen Fiss. Both took advantage of the highly visible forum provided by the Harvard Law Review's annual Supreme Court Foreword. Both were notable, not merely for the defenses of the new litigation but also for their efforts to define its essential characteristics.

Chayes's 1976 Foreword begins by contrasting the traditional model of litigation with the emerging new model. The traditional lawsuit is bipolar (a contest between two opposing interests), retrospective (focusing on past events), rights driven (the remedy derives from the wrong), self-contained (limited in time and scope); and party driven (with the judge acting as referee) (Chayes 1976, 1282-83). In contrast, the new model has a "sprawling and amorphous" party structure, an infusion of negotiation and mediation at every point, and a judge who actively orchestrates the proceedings. Most important, "the trial judge has increasingly become the creator and manager of complex forms of ongoing relief, which have widespread effects on persons not before the court and require the judge's continuing involvement in administration and implementation" (Chayes 1976, 1284). These characteristics, in his view, were not wholly novel, but derived from the long tradition of equity litigation (Chayes 1960, 1303; see also Eisenberg and Yeazell 1990).

Chayes made several arguments in defense of this form of litigation. Remarking that judges, like other government actors, "have exercised a large and messy admixture of powers," he was untroubled by the separation of powers issue (Chayes 1976, 1307-9). For Chayes, the ultimate test of legitimacy was "the ability of a judicial pronouncement to sustain itself in the dialogue" with other political forces and to "generate assent over the long haul." This legitimacy, he contended, can be achieved only when judges are "responding to ... the deep and durable demand for justice in our society" (Chayes 1976, 1316).

Although Chayes in passing contrasted his view with Fuller's (Chayes 1976, 1304), Fiss provided a much more radical challenge to Fuller. According to Fiss, the basic error made by Fuller (and echoed by Chayes) was to view mere dispute resolution as the central task of adjudication. Dispute 
resolution, in his view, is a job for arbitrators, not judges; the role of the judge is to articulate social values and give them concrete form (Fiss 1979, 29, 39-44).

Fiss contended that Fuller's resistance to polycentric adjudication was based fundamentally on the impossibility of allowing "everyone affected to participate in the lawsuit in a meaningful way." As Fiss explained, the right to individual participation conflicts with "the kind of representation lying at the heart of a structural suit-the representation of interests by spokesmen for groups and officers rather than identifiable individuals" (Fiss 1979, 40-41). Fiss argues, however, that group litigation is not really an incursion on personal autonomy. Rather, "what is needed to protect the individual is the establishment of power centers," such as the courts, "equal in strength and equal in resources to the dominant social actors" (Fiss 1979, 44).

Although his Foreword seemingly presents an enthusiastic defense of strenuous judicial activism, Fiss's views at the time may actually have been somewhat more nuanced. A year earlier, he had written that the scope of judicial intervention should be based on a "more complex form of analysis, one that takes into consideration such factors as the importance of the claim for the eradication of caste structure and the magnitude of the social dislocation that would be caused by honoring the claim" (Fiss 1978, 94-95). What he was at pains to defend in the Foreword was not a policy of relentless judicial intervention but rather the legitimacy of broad judicial intervention when warranted by circumstances. Still, there is no doubting his admiration for the work of judges like Henley in the Arkansas prison litigation:

It was not reasonable to expect the judges to be heroes, but the truth of the matter is that [in the civil rights era] many lived up to these unreasonable expectations - they fought the popular pressures at great personal sacrifice and discomfort. The average judge turned out to be more heroic than the average legislator (or juror). (Fiss 1978, 90) ${ }^{5}$

\section{B. Critiques of Structural Litigation}

Opposing Chayes and Fiss were outspoken critics of structural litigation. Essentially, their criticisms were threefold: that structural litigation is ineffective, inconsistent with the rule of law, and unconstitutional.

5. Other defenses of institutional litigation were more guarded William Fletcher, himself now a federal appeals judge, argued that structural decrees involved the exercise of essentially political judgment and hence were presumptively illegitimate, but that the presumption could be overcome "when the political bodies that should ordinarily exercise such discretion are seriously and chronically in default" (Fletcher 1982, 637). 
The effectiveness point is not central to Feeley and Rubin's analysis but deserves brief consideration. Largely as a reaction to earlier exaggerated claims on behalf of the judiciary, a revisionist school of thought contends that federal judges have made little or no contribution to social reform. Prison litigation, however, is not a particularly good example for the revisionists. Gerald Rosenberg, a leading revisionist, says only that the prison cases failed to achieve complete success: "while some changes have been made, serious problems remain," and "change has been uneven." He concedes that "[m]any of the worst conditions have been improved to at least minimal standards, but problems still abound" (Rosenberg 1991, 306-7). The apparent concession is that the litigation was at least partly effective. Indeed, the significant impact of prison litigation seems nearly undeniable (Sturm 1993, 660-81).

The second criticism is that, by involving the courts in an essentially inappropriate task, structural litigation violated the rule of law. Even some moderate defenders of structural litigation like Fletcher were troubled by this point (Fletcher 1982, 647). The critics argued that structural injunctions "are so widespread in part because they so frequently are not prompted by, nor at they aimed at achieving, any independently ascertainable legal standard," being based instead on "moral hubris and intellectual confusion" (Nagel 1984, 401). Subsidiary arguments were that structural injunctions led to biased decision making, as judges assumed an adversarial role toward noncomplying defendants; to intrusions on the democratic process, as judges attempted to thwart opponents of their orders; to overly broad remedies unrelated to any violation of the law; and to coercion of nonparties who had never had the opportunity to be heard (Nagel 1984, 403-7).

Finally, critics argued that the structural injunctions were plainly unconstitutional. Most obviously, they said, structural injunctions violated the separation of powers: "Just as the President cannot assume the judicial powers of a state and decide all cases therein, and Congress cannot assume executive power and seize operational command of a state's militia, so too the federal courts cannot assume state executive and legislative powers" (Yoo 1996, 1165). Thus, structural injunctions are destructive of state legislative and administrative functions, taking the courts beyond their proper sphere (Nagel 1984, 398). With respect to federalism, critics argued that such judicial intrusions into previously local issues would undermine "the vitality of self-government at the local level ... jeopardizing the complex and symbiotic relationships among private associations, political parties, and the various levels of government that have characterized the American political system since de Tocqueville's time" (Nagel 1984, 399). 


\section{Feeley and Rubin's Response: An Overview}

How do Feeley and Rubin respond to this indictment? In part, they agree with the critics:

To begin with, [the prison reform process] violated the principle of federalism. . . . All the familiar furniture of federalist doctrine-the virtues of citizen involvement, the division of power among separate jurisdictions, the opportunity for experimentation-was cast aside as federally imposed standards restructured state institutions and displaced state decision makers.

Second, the prison reform process violated the separation of powers principle. In the process of defining and imposing standards, courts undertook the management and micromanagement of these institutions. ... Even when courts acted without appointing subordinate officials [such as special masters], they maintained an ongoing, detailed supervision of the institution that diverges from our traditional image of judicial action and judicial standard setting. (P. 18)

Moreover, Feeley and Rubin also concede that prison reform violated the "principle that judicial action should be guided and constrained by preexisting law." Although courts invoked the Eighth Amendment, the "rules were simply too detailed ... for that explanation to be credible" (p. 18).

Yet, despite this concession to the critics, Feeley and Rubin argue that the prison cases were entirely legitimate. Essentially, while they concede that the prison cases do not fit existing concepts of federalism, separation of powers, and the rule of law, they attack those traditional concepts as intellectually bankrupt. The modern administrative state, they say, "is the principal force behind the decreasing relevance of federalism, separation of powers, and our traditional notion of the rule of law" (p. 23). In today's world, separation of powers and federalism have little real substance; the only viable structural principle is that of "checks and balances" (p. 383; see also p. 345). Although dismissive of federalism and the separation of powers, Feeley and Rubin do embrace the rule of law. They argue, however, that it needs to be understood to include an active policymaking role for the courts.

Judicial policymaking, as the book's title indicates, is a key concept for Feeley and Ruben. They define it as the "exercise of power" by officials "on the basis of their judgment that their actions will produce socially desirable results" (p. 5). Policymaking is distinct from interpretation, where courts find guidance in legal texts. When judges are engaged in policymaking, some text (such as the Eighth Amendment in the prison cases) provides a "source of jurisdiction, not a guide to action" (p. 5; see also p. 337).

All of this may sound very radical in its implications, as if Feeley and Rubin envision some massive federal bureaucracy in control of the country, 
backed up by wildly activist judges. But they are actually calling, not for a drastic change in our present institutional arrangements, but for a reconceptualization of those institutions. They cheerfully concede the importance of decentralizing national power, of checks and balances, and of restraints on judicial activism. But they view the traditional apparatus for thinking about these issues to be largely a relict of past centuries.

The notion of judicial policymaking may seem alarmingly unbounded, but Feeley and Rubin see it as profoundly constrained by the need for individual judges to win the assent of the judiciary as a whole and the support of other government actors. Judges, who have internalized the norms of the legal system, "feel that they are governed, although no outside actor is governing them, and that they are thus conforming to the rule of law" (p. 353). Unlike other observers (Kennedy 1997), Feeley and Rubin do not view the judiciary as fundamentally indistinguishable from other government agencies, nor do they see the rule of law as a facade behind which raw politics reigns supreme.

\section{STRUCTURAL REMEDIES AND THE CONSTITUTION}

For many readers, the most startling aspect of this book may be its insistence that federalism and the separation of powers are defunct, an insistence that may seem eccentric in light of the Supreme Court's increasingly frequent invocation of these doctrines. But, as we will see, Feeley and Rubin's arguments are not insubstantial.

\section{A. Separation of Powers}

Feeley and Rubin consider several possible arguments for enforcing the separation of powers. The first is that particular institutions are best suited for specific functions, and therefore should be limited to those functions. Feeley and Rubin concede the premise but deny the conclusion. At most, they say, this argument offers only a caution: It might be "unwise for a polar bear to live in the Sahara, or for a court to undertake administrative functions, but we would hardly call it immoral." Moreover, "if the bear had no other place to live, or the government had no other institution that could undertake those functions, it would make perfect sense for each of them to do their best, despite the inefficiency" (p. 314). Furthermore, they say, courts actually managed fairly well in performing administrative functions in the prison cases (pp. 320-21). ${ }^{6}$

6. Fuller might have been surprised that the courts were as successful as they were, though he might have merely viewed the prison cases as an example of "mixed adjudication," 
A related, more formalist argument is that the Constitution confines each branch to performance of particular functions, so that courts may exercise the "judicial power" but not the "executive power." But this formalist thesis presumably ought to have a formalist basis, and neither the text nor original understanding provide clear support for it. Such support seems particularly scanty with respect to the pure "dispute resolution" model of the judicial power, since judges during the founding era actually performed a variety of governance functions (pp. 323-30).

The most serious separation of powers argument also goes by the name of "the counter-majoritarian difficulty." What warrant do unelected judges have for invading the policymaking prerogatives of the other, more democratic branches of government? Feeley and Rubin attempt to dispose of this argument in a few pages. Their view is that courts are an integral part of the governing apparatus and partake of the overall democratic nature of that governance (pp. 330-35). The argument is probably sketched too briefly to persuade anyone but the already converted. But the argument is not implausible if-and this is a major "if"-the reader agrees with their overall thesis that the judiciary is inherently constrained in its efforts to make and implement social policy.

As to their general attack on the separation of powers, the argument seems most persuasive if the separation of powers is conceived in formalist terms, as involving bright-line separations between branches of government. But if we think of the separation of powers in looser, more institutionalist terms-as involving a strong normative resistance against one branch taking on the usual functions of other branches-it is far from clear that the principle is dead.

Indeed, the separation of powers may exercise its greatest force, not by serving as a defined limit on decision making but by making certain kinds of government actions unthinkable. If we did not have a deeply embedded conception of separated powers, courts could have dealt with the prison cases in a far more straightforward way. They could simply have appointed new prison administrators and taxed state residents to pay for the improvements. But not even the most activist judge seems to have considered these options.

In some sense, then, separation of powers is such a bedrock principle of our system of government that its operation is almost invisible. Asking whether one believes in the separation of powers is reminiscent of the old joke about the man who was asked if he believed in infant baptism. "Believe 
in it?" he responds, "Why, I've seen it done!" As an institutional matter, separation of powers is a reality, not just a legal principle.

\section{B. Federalism}

Feeley and Rubin's attack on federalism is more sustained than their challenge to the separation of powers. It is important at the outset to understand the nature of their target. They distinguish federalism from decentralization, so that continued state authority over prisons is consistent with what they call their "direct and total rejection of the federalist principle" ( $p$. 172). In their view, "[f]ederalism is not a managerial decision by the central decision maker, as decentralization can be, but a structuring principle for the system as a whole" (p. 173). Federalism, in their view, involves only the right to choose fundamentally different goals than the rest of society (pp. 174-75). Since the plantation model of prisons was just such a normative choice-indeed, one of the most striking surviving examples of such a normative choice-rejection of this model by the federal courts was the end of true federalism in America (p. 176). So say Freeley and Rubin.

Feeley and Rubin attack federalism, as so conceived, on a variety of grounds. Most of the standard justifications for federalism, they say, involve decentralization rather than "true" federalism. Other federalism arguments mistakenly attribute to state governments communitarian virtues they do not possess. Moreover, as the prison cases show, restricting federalism can actually increase liberty, by providing a check against state tyranny (pp. 177-203). In the course of their discussion, they deftly poke holes in much of the recent revival of federalism in legal scholarship.

The argument seems well taken, so far as it goes, but just how far does it actually go? As a matter of pure institutional description, federalism surely continues to exist. It did not occur to any federal court, for instance, to fix state prisons by transferring their management to the Justice Department. No doubt Feeley and Rubin would consider this only evidence of decentralization (rather than federalism). But if "federalism," as defined by Feeley and Rubin, is defunct, then why cannot decentralization be considered a constitutional principle?

Feeley and Rubin view decentralization as subconstitutional for two reasons: it is a decision made by the central authority rather than a right of the smaller units (p. 180), and it is only "part of a pragmatic calculus of governance" and can "no longer carry normative force" (p. 343). But surely,

7. Some form of separation of powers is probably also essential to the checks and balances that Feeley and Rubin rightly endorse The courts were checked by the need to obtain cooperation from prison authorities and legislators only because they lacked the authority to take over these tasks themselves. Aggrandizement of additional powers by one branch could eventually undermine the ability of the other branches to administer checks. 
by their own lights, this is too formalistic an account. Their general strategy of institutional analysis should make them wary about speaking of decentralization as a decision by the "central authority." There is no central authority; there are only federal judges, legislators, and administrators. Although implemented by part of the "central authority"-the Supreme Court-constitutional limits on the power of the national government qualify as "federalism" by any ordinary definition. If the question is whether federal judges should recognize legal doctrines that protect decentralization in some way, Feeley and Rubin are the last people who should denounce the effort as mere policymaking. Thus, federalism seems to be a potentially valid option for the federal judiciary under Feeley and Rubin's own view of the judicial role.

In short, although Feeley and Rubin have many interesting insights about the federalism and separation of powers debates, their efforts to sweep these concepts from the board seem unsuccessful. To turn one of their own wonderfully crafted phrases against them, while no knock-down argument against their position exists, "the energy they must expend to swim upstream against the obvious" suggests that theirs is "not the most useful explanation" (p. 11). For better or worse, neither separation of powers nor federalism is safely dead and buried.

This leaves us with the puzzle that prompted their theorizing: given the blatant expansion of federal judicial power at the expense of state legislators and executives, why were federalism and separation of powers nonissues for the judges in the prison cases? Why weren't judges at least severely troubled, if not stopped in their tracks, by these concerns?

The answer, I think, is that having found a constitutionally intolerable situation, the federal courts had very little choice. In finding that a violation of the Constitution existed, they were not formally constrained by the separation of powers, since applying the Constitution is a core judicial task, nor by federalism, since the Fourteenth Amendment (as presently understood) deprives the states of any authority to violate the key requirements of the Bill of Rights. Nor, it seems clear, does Article III prevent courts from overseeing complex institutional arrangements; judicial supervision of complex institutions has a long pedigree (Eisenberg and Yeazell 1980). Nor were courts restricted in their constitutional analysis by any more functionalist notions of federalism and separation of powers: torturing and starving prisoners is not a legitimate executive or legislative function, nor is it a legitimate exercise of state autonomy. So the finding of liability was unproblematic.

But once judges found a constitutional violation, they were inevitably forced into a sweeping remedy. They could not simply content themselves with announcing that a massive violation of human rights was taking place, hoping that someone else might conceivably step in to remedy the situa- 
tion. They could not close all the prisons and release the prisoners. Their only option was to try, as best as possible, to remedy the situation, using whatever means of action and whatever standards came to hand. This inevitably involved them in an unaccustomed role, one that raised serious doubts about both their ability and authority. But what else could they do?

Anyone who thinks that scruples about remedial power could save the Tucker Telephone and its ilk is asking more (or less) than one could ask of human judges. And once the process was begun, it developed its own momentum, as the courts struggled to find remedial strategies. The precedents set in the states with the most horrific conditions gave other judges the authority to act in less dramatic, but still disturbing situations.

Thus, for all the debate among scholars about structural injunctions, the decisive stage of the prison litigation really took place when the judges decided that current conditions were intolerable. But was this kind of policy decision itself legitimate? This question brings us to the intellectual core of the book, its theory of judicial policymaking.

\section{JUDGES AS POLICYMAKERS}

Feeley and Rubin put little faith in pure logic as an engine for creating doctrine. Thus, they say, the logic of contract law is about like the logic of a lasagna recipe: "[t]he individual elements relate to a definable entity and are comprehensible as a single body of rules, but they are not derived from each other or from some overarching principle" (p. 252). Feeley and Rubin staunchly defend the authority of judges to make social policy when the governing legal texts are too open-ended to provide real guidance. Indeed, they view such as policymaking as central to the creation of all legal doctrine. ${ }^{8}$ I will review their model of how such policymaking is effectively channeled and then attempt to assess their model.

\section{A. Feeley and Rubin's Model of Policymaking}

Feeley and Rubin contrast policymaking with interpretation, although admitting that the two can overlap. In interpretation, the judge actually discerns some rule of decision in the governing text; in policymaking, the text provides only an authorization for the judge to act (p. 5).

8. They appear to assume that if policymaking is justified in the common law and statutory settings, it is also appropriate in constitutional law Apart from their brief discussion of the countermajoritarian difficulty, however, they do not devote much attention to this point. The analogy to common law seems strongest in connection with judicial creativity in crafting remedies, which seems to involve a kind of constitutionally inspired federal common law. 
The basic judicial mechanism of policymaking involves "translation of policy goals into legal doctrine" (p. 210). For the individual judge, the process proceeds in three steps:

1. Doctrine: the evaluation of existing law. Feeley and Rubin reject the view that doctrine is always indeterminate, and they view judges as motivated by their institutional roles to follow doctrine (pp. 211, 215-16).

2. Attitude: the judge's view of policy. The judge perceives that the doctrinal result is incompatible with policy. Judges dislike making policy and will abandon reliance on authoritative texts only "when they have some assurance that the beliefs that motivate them are strongly felt and widely held, that is, that these beliefs are truly elements of social morality" (p. 219).

3. Integration: reconciling doctrine and policy. Given a sharp conflict between attitude and doctrine, the judge could ignore one or the other completely, at some professional or personal cost. But a more attractive course is to resolve the conflict by integrating the two through a shift in doctrine. This shift is usually rationalized on the basis of general legal principles that legitimate doctrinal change (pp. 223-24).

So far, there is nothing startling here, except perhaps for those who think either that judges are either entirely result oriented or entirely driven by doctrine.

At this point, however, the argument takes an intriguing turn. Jurisprudential theories generally focus on the decision making of the single judge. Feeley and Rubin argue, however, that the creation of doctrine is inherently a group activity. If new doctrine percolates up "from below," it must win the spontaneous assent of multiple trial judges, as in the prison cases. If it comes from "above," it must initially attract the support of a majority on an appellate court and must also be reasonably acceptable to lower court judges, who will otherwise distinguish it away or otherwise evade it (pp. 229-31).

So far, these observations may seem somewhat mundane, but Feeley and Rubin argue that the need to win unforced support from numerous judges is actually a powerful constraint. To win this support, an innovation must have several characteristics. The doctrinal innovation must be "fully realized"- that is, sufficiently developed that its application is clear (i.e., it must be a "doctrine," not merely a theory or an insight) (pp. 233-34). It must also take place incrementally, because larger-scale changes would be too hard to coordinate among multiple judges (pp. 234-235). Finally, it must typically move along with what judges think are the overall trends in the law (p. 236). 
Does this process comply with the rule of law? Feeley and Rubin think it does. They view the rule of law as involving a kind of mutual restraint by judges:

To be more specific, coordinating ideas in the judicial context must be fully realized, must be incremental, and must usually reflect the prevailing directionality of law.... These are severe, albeit not determinative, constraints. The judge who is subject to them is unlikely to experience a sense of unrestrained freedom; instead, she will perceive herself as struggling to find the most persuasive formulation from among a very limited range of possibilities. That sense of limitationof conscientious striving to find an acceptable solution, rather than of self-indulgent exultation at imposing one-constitutes the rule of law for the judiciary. (P. 242)

True, they admit, "the internal dynamics of the coordination process do not provide clear guidance for an individual judge or definitive constraints on her decisions." Instead, "[w]hat is being constrained is not each individual judge but the judiciary as an institution" (p. 243).

But is this process undemocratic? Here, too, Feeley and Rubin have answers. The first is that texts such as constitutional provisions do not dictate the results of judicial policymaking but do confine it within certain fields of operation. ${ }^{9}$ The second is that "policymaking is an intrinsic or indwelling element of the judicial process" so that "when courts are granted jurisdiction the potentiality of policy making is inherent in that grant" ( $p$. 359).

\section{B. Assessing Judicial Policymaking}

Feeley and Rubin's description of how doctrine is created seems realistic enough. Moreover, at least in broad general terms, this kind of policymaking seems so basic to the evolution of legal doctrine that it can hardly be incompatible with the rule of law. Or at least, if the answer is otherwise, then no common law country ever had the rule of law and perhaps no civil law country as well. For the same reason, it is hard to believe that this process is inherently inconsistent with democracy, for if so, we have apparently been living unknowingly in a nondemocratic regime all along.

All this being said, judicial policymaking, particularly in the constitutional sphere, remains troubling, for all the familiar reasons. The institutional factors discussed by Feeley and Rubin, along with other checks on the

9. This answer might be more convincing if the Court had not given provisions such as the due process clause such an open-ended interpretation. As it is, any sharp boundaries in the domain of judicial activism are hard to discern. 
judiciary, do make any fear of large-scale "judicial tyranny" unrealistic. The same institutional factors may even insure that in the long run the results of the process are usually acceptable to society at large. Still, misguided judicial interventions retain the capacity to do significant harm before they are curbed. Feeley and Rubin's effort to make judges feel entirely at ease with the process may not be salutary. Perhaps it is best for judges to have an occasional nagging feeling that policymaking is a slightly risque activity in a democracy (so long as the nagging feeling does not translate into compulsive handwashing and other neurotic obsessions with judicial restraint). Judicial policymaking can be invaluable, but it is also possible to have too much of a good thing.

If the prison cases were the norm rather than the exception, it would be hard to distinguish courts from administrative agencies. Indeed, the larger theme of the book is that the prison cases, like other examples of judicial policymaking about institutions, are simply a sign that judges, too, are a part of the administrative state (pp. 342-44). It is true that many of the objections to the prison cases have a striking resemblance to some standard objections to administrative agencies: that they mix legislative, executive, and judicial powers; that their procedures do not correspond to historical categories; and that they are prone to expand their powers at the expense of other government authorities such as the states. ${ }^{10}$ Today, at least some would question the legitimacy of the administrative model itself, a challenge that Feeley and Rubin may not take seriously enough. But even putting that challenge aside, it is by no means clear that what is appropriate for an administrative agency is equally so for a court. Presumably, there was good reason why administrative agencies were created, rather than merely assigning their duties to existing institutions such as courts.

In the end, what Feeley and Rubin call the modern administrative state is just that: administrative rather than judicial. Institutional litigation may be the exception that proves the rule. But even if we reject their more sweeping conclusions, there can be no doubt that they have substantially contributed to the debate.

\section{CONCLUSION}

In Judicial Policy Making and the Modern State, Feeley and Rubin have produced a kind of tour de force in legal theory. Besides offering a lively history of the prison reform litigation itself, they have provocative and often incisive comments on core issues of constitutional theory such as federalism, separation of powers, and the role of the federal courts. All of this is com-

10. Another concern, fear of capture by regulated entities, is probably less an issue with courts than with agencies. 
bined with a jurisprudential perspective that draws on a wide reading within law, philosophy, and political science.

More specifically, the book makes several significant contributions. First, it provides a good perspective on the long-running debate over institutional litigation. Second, it effectively debunks at least some formalist notions of federalism and separation of powers as constraints on judges. Third, it provides an innovative description of how the inherently collective nature of the judiciary constrains outcomes and promotes the rule of law.

At a more basic level, Feeley and Rubin show that purely abstract analyses of the judicial role are unlikely to provide much insight. Instead, theorizing must be interlaced with careful explorations of how judges actually operate in important cases and of the institutional setting in which they act. Perhaps my major criticism is that Feeley and Rubin do not take their own methodology far enough. Rather than examining how federalism and separation of powers enter into decision making and are embedded in institutional structures, they are content to analyze them as logical propositions. Nevertheless, in its methodology, the book is undoubtedly a substantial step in the right direction. If other analysts follow its path, our understanding of the judicial process will be enriched.

\section{REFERENCES}

Chayes, Abram. 1976. The Role of the Judge in Public Law Litigation. Harvard Law Review 89:1281-1316.

Coffin, Frank. 1979. The Frontier of Remedies: A Call for Exploration. Califormia Law Review 67:983-99.

Decker, Deborah. 1997. Consent Decrees and the Prison Litigation Reform Act of 1995. Wisconsin Law Review 1997:1275-1321.

Diver, Colin. 1979. The Judge as Political Powerbroker: Superintending Structural Change in Public Institutions. Virginia Law Review 65:43-106.

Eisenberg, Theodore, and Stephen Yeazell. 1980. The Ordinary and the Extraordinary in Institutional Litigation. Harvard Law Review 93:465-517.

Eskridge, William. 1989. Metaprocedure. Yale Law Journal 98:945-74.

Fiss, Owen. 1978. The Civil Rights Injunction. Bloomington: Indiana University Press. - 1979. The Supreme Court, 1978 Term-Foreword: The Forms of Justice. Harvard Law Review 93:1-58.

Fletcher, William. 1982. The Discretionary Constitution: Institutional Remedies and Judicial Legitimacy. Yale Law Journal 91:635-97.

Fuller, Lon. 1978. The Forms and Limits of Adjudication. Harvard Law Review 92:353-409.

Kennedy, Duncan. 1997. A Critique of Adjudication (fin de siècle). Cambridge, Mass.: Harvard University Press.

Klarman, Michael. 1996. Rethinking the Civil Rights and Civil Liberties Revolutions. Virginia Law Review 82:1-67.

Liebman, James. 1990. Desegregating Politics: "All-Out" School Desegregation Explained. Columbia Law Review 90:1463-1665. 
Nagel, Robert. 1984. Controlling the Structural Injunction. Harvard Joumal of Law and Public Policy 7:395-411.

Rosenberg, Gerald. 1991. The Hollow Hope: Can Courts Bring about Social Change? Chicago: University of Chicago Press.

Sturm, Susan. 1990. Resolving the Remedial Dilemma: Strategies of Judicial Intervention in Prisons. University of Pennsylvania Law Review 138:805-912.

1993. The Legitimacy and Future of Corrections Litigation. University of Pennsyluania Law Review 142:639-738.

Yoo, John. 1996. Who Measures the Chancellor's Foot? The Inherent Remedial Authority of the Federal Courts. Califomia Law Review 84:1121-77. 